The Concentration and Distribution of Depleted Uranium (DU) and Beryllium $(\mathrm{Be})$ in Soil and Air on Illeginni Island at Kwajalein Atoll

W. L. Robison, T. F. Hamilton, R. E. Martinelli, F. J. Gouveia, T. R. Lindman, S. C. Yakuma

June 14, 2006 
This document was prepared as an account of work sponsored by an agency of the United States Government. Neither the United States Government nor the University of California nor any of their employees, makes any warranty, express or implied, or assumes any legal liability or responsibility for the accuracy, completeness, or usefulness of any information, apparatus, product, or process disclosed, or represents that its use would not infringe privately owned rights. Reference herein to any specific commercial product, process, or service by trade name, trademark, manufacturer, or otherwise, does not necessarily constitute or imply its endorsement, recommendation, or favoring by the United States Government or the University of California. The views and opinions of authors expressed herein do not necessarily state or reflect those of the United States Government or the University of California, and shall not be used for advertising or product endorsement purposes.

This work was performed under the auspices of the U.S. Department of Energy by University of California, Lawrence Livermore National Laboratory under Contract W-7405-Eng-48. 


\section{Table of Contents}

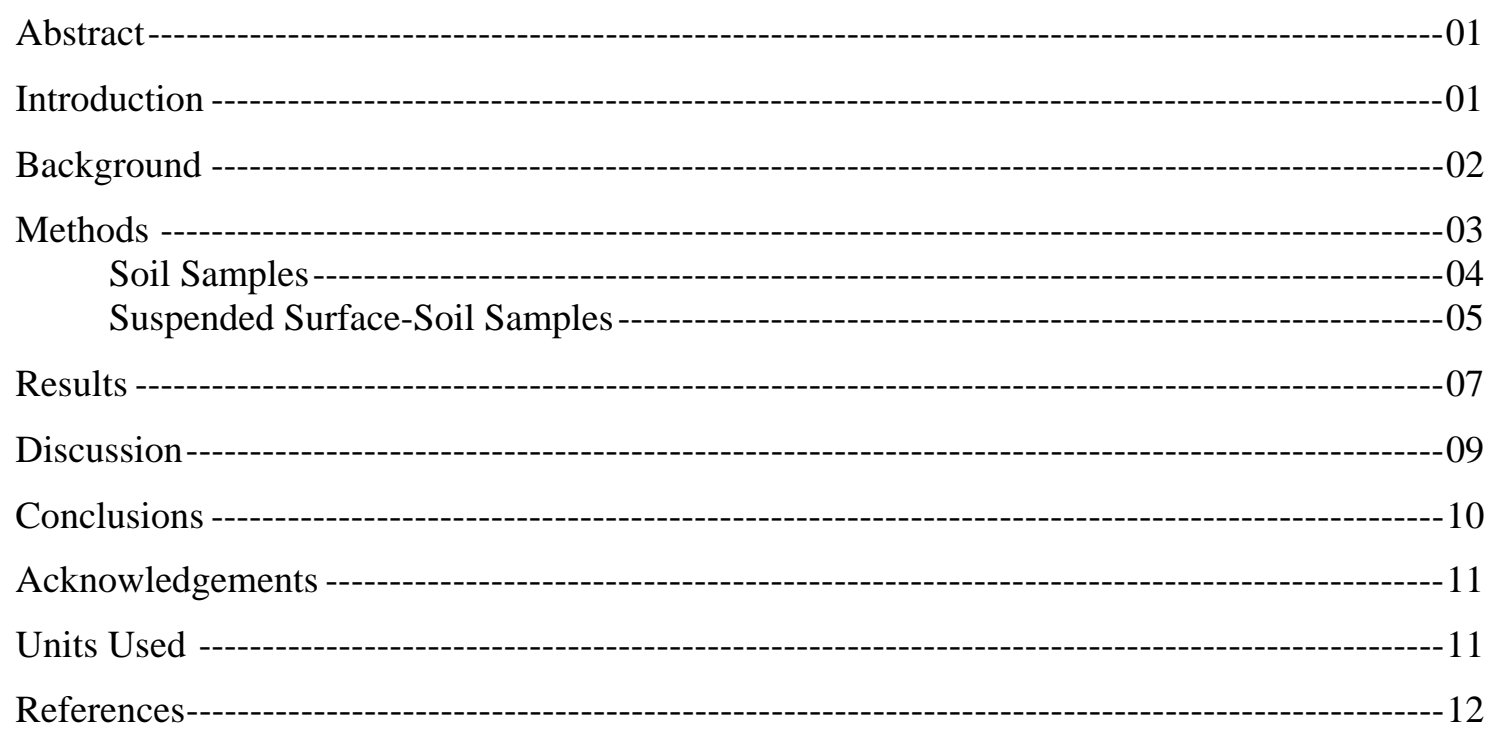

APPENDIX A: Uranium and Be concentration in all soil samples from Illeginni Island at

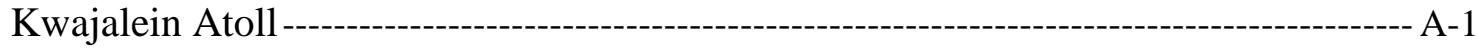




\section{List of Tables}

Table 1. Concentrations of U and Be in Soil at Illeginni Island. -------------------------- 07

Table A-1. Uranium and Be concentration in all soil samples from Illeginni Island at

Kwajalein Atoll. ---------------------------------------------------------------------------------- A-1

\section{List of Figures}

Figure 1. Map of Illeginni Island at Kwajalein Atoll. --------------------------------------- 02

Figure 2. Map of the area on Illeginni Island where deposition of materials occurred. 04

Figure 3. Illeginni Island grid with $\mathrm{U}$ and Be data at each sampling site.---------------- 05

Figure 4. Beryllium concentration versus depth in soil profiles on Illeginni

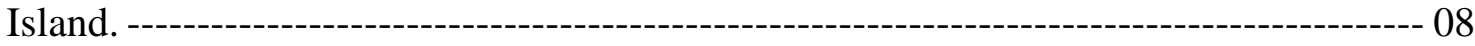

Figure 5. Uranium concentration versus depth in soil profiles on Illeginni

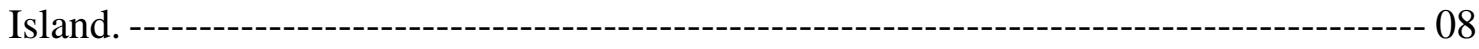

Figure 6. The concentration of $\mathrm{U}$ and $\mathrm{Be}$ in air at Illeginni Island. ----------------------- 10 


\title{
The Concentration and Distribution of Depleted Uranium (DU) and Beryllium (Be) in Soil and Air on Illeginni Island at Kwajalein Atoll
}

\author{
William L. Robison, Terry F. Hamilton, Roger E. Martinelli, Frank J. Gouveia, \\ Terry R. Lindman, and Stephen C. Yakuma
}

\begin{abstract}
Re-entry vehicles on missiles launched at Vandenberg Air Force base in California re-enter at the Western Test Range, the Regan Test Site (RTS) at Kwajalein Atoll. An environmental Assessment (EA) was written at the beginning of the program to assess potential impact of Depleted Uranium (DU) and Beryllium (Be), the major RV materials of interest from a health and environmental perspective. The chemical and structural form of $\mathrm{DU}$ and $\mathrm{Be}$ in $\mathrm{RVs}$ is such that they are insoluble in soil water and sea water. Consequently, residual concentrations of DU and Be observed in soil on the island are not expected to be toxic to plant life because there is essentially no soil to plant uptake. Similarly, due to their insolubility in sea water there is no uptake of either element by marine biota including fish, mollusks, shellfish and sea mammals. No increase in either element has been observed in sea life around Illeginni Island where deposition of DU and Be has occurred.

The critical terrestrial exposure pathway for $U$ and Be is inhalation. Concentration of both elements in air over the test period (1989 to 2006) is lower by a factor of 10,000 than the most restrictive U.S. guideline for the general public. Uranium concentrations in air are also lower by factors of 10 to 100 than concentrations of $U$ in air in the U.S. measured by the EPA (Keith et al., 1999). $U$ and Be concentrations in air downwind of deposition areas on Illeginni Island are essentially indistinguishable from natural background concentrations of $U$ in air at the atolls. Thus, there are no health related issues associated with people using the island.
\end{abstract}

\section{Introduction}

Lawrence Livermore National Laboratory (LLNL) has supported the United States Air Force (USAF)/Department of Energy (DOE) Peacekeeper and Minuteman ballistic missile flight test program for LLNL and Los Alamos National Laboratory (LANL) re-entry vehicles (RVs) from 1988 through 2006 for tests targeted for the Western Test Range, the Regan Test Site (RTS), at the U. S. Army base at
Kwajalein Atoll (USAKA). Re-entry vehicles on missiles launched at Vandenberg Air Force base in California re-enter at the RTS. Some RVs are targeted in the vicinity of Illeginni Island (Figure 1) at Kwajalein and LLNL has supported scoring, recovery operations of $\mathrm{RV}$ materials, and assessments of the environmental and health impacts of associated materials in the targeted area. 


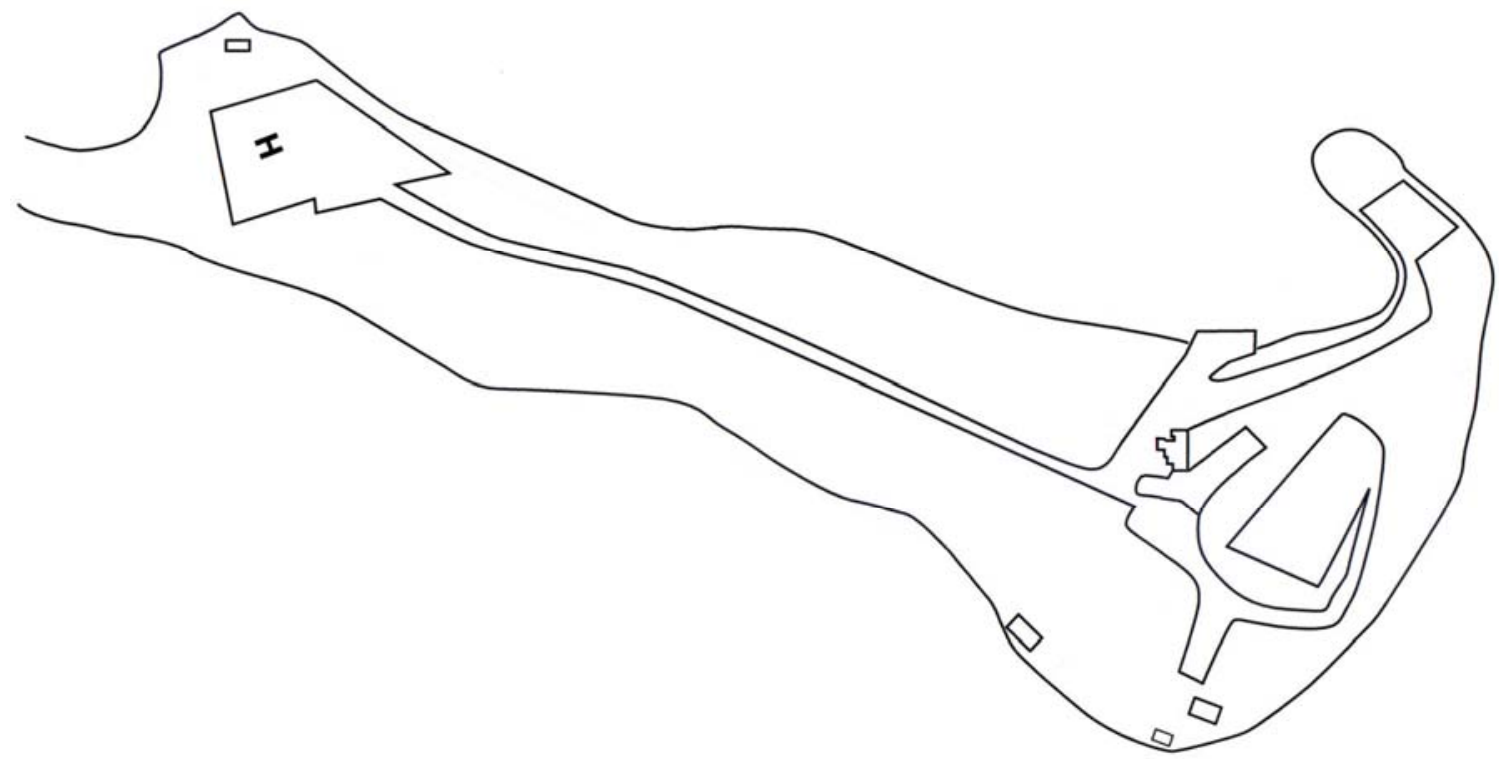

Figure 1. Map of Illeginni Island at Kwajalein Atoll.

\section{Background}

An environmental Assessment (EA) was written at the beginning of the program to assess potential impact of DU and $\mathrm{Be}$, the major $\mathrm{RV}$ materials of interest from a health and environmental perspective (Robison and Shinn, 1988), if land impact should occur. A more extensive EA was written in 1992 (Robison and Cederwall, 1992). Periodic reports have been submitted by LLNL over the years to USAKA and RTS range commanders detailing the Uranium (U) and Be concentrations in soil and air at Illeginni Island as a result of land impacts (Robison and Shinn, 1990; Robison, 1992). Moreover, letters have been submitted after each mission to the USAKA commanding officer and Range Operations commander describing whether or not there was a land impact. If there was a land impact then recovery operations were begun to look for classified components and air samplers were deployed to determine the total concentration of $U$ (DU plus natural $U$ ) and Be in air. Surface soil samples were also collected and analyzed for U (DU plus natural $U$ ) and Be. These data were sent to the USAKA commanding officer and range command personnel. Recently, the USAF completed a thorough, updated EA (USAF, 2004) that included LLNL data previously supplied to USAKA.

Although DU is radioactive (much less so than natural $U$ ) it is not a radiological health concern but a toxicity health concern (Keith et al., 1999; Durante and Pugliese, 2002, Bleise et al., 2003; Assimakopoulos, 2003; Meinrath et al., 2003; Mc Diarmid et al., 2004). The chemical and structural form of the DU and Be in $\mathrm{RVs}$ is such that they are insoluble in soil water and sea water. Thus, they are not toxic to plant life on the island (no soil to plant uptake). A good demonstration is the flourishing plant life on the island where DU and Be have been deposited. Concentrations of soluble Be in soil have to exceed about $2 \mu \mathrm{g} \mathrm{g}^{-1}$ for plants to start showing toxic 
effects (see review by Shinn et al., 1988). As a result of the lack of uptake of Be and $U$ by plants on Illeginni, there is no exposure to humans from the ingestion pathway from consumption of coconuts, Pandanus fruit, or other food crops.

Similarly, due to insolubility of the two materials in sea water there is no uptake of either element by marine biota including fish, mollusks, shellfish, and sea mammals.. If either material were even slightly soluble in sea water the soluble ions would rapidly mix with the worlds oceans and be indistinguishable from the natural concentration of $3 \mathrm{mg} \mathrm{L}^{-}$ ${ }^{1}$ for $\mathrm{U}$ and $6 \mathrm{ng} \mathrm{L}^{-1}$ for Be in sea water (McWright, 1996). No increase in either element has been observed in sea life around Illeginni Island where deposition of DU and Be has occurred (Robison et al., 2005). As a result, there is no impact on marine flora and fauna and there would be no exposure to humans from ingestion of marine foods.

When RVs impact on land, particles of DU and Be are dispersed on the soil surface over small areas of the island. Some amounts of both materials are also deposited deeper in the soil within the crater produced by RV land impact. Inhalation of DU and Be is considered the critical pathway for exposure to these materials distributed on the ground surface (Bleise et al., 2003; Keith et al., 1999). Leaching into a drinking water supply can also be an issue for some $U$ and Be compounds but because of the chemical and structural form of the $\mathrm{U}$ and
Be on Illeginni, and the lack of a fresh water supply (i.e., the ground water is saline and non-potable), inhalation is the critical route of exposure.

Thus, DU and Be in surface soil provide a potential source of exposure to people via inhalation if the materials, as a result of wind-driven processes, are re-suspended from the soil surface. U.S. federal guidelines for $\mathrm{U}$ and $\mathrm{Be}$ are all for concentrations in air. The most restrictive United States guidance is for the general public. Work-area standards are significantly higher than those for the general public. The U.S. Environmental Protection Agency (EPA) guideline for Be for the general public is $0.01 \mu \mathrm{g} \mathrm{m}^{-3}$ in air (40 CFR 61.32, 2003). For comparison, Occupational Safety and Health Administration (OSHA) workplace 8-h time-weighted average is $2 \mu \mathrm{g} \mathrm{m}^{-3}$ and the 15-minute time-weighted average is $25 \mu \mathrm{g} \mathrm{m}^{-3}$ (29 CFR 1910.1000, 2003). The OSHA guidelines have been adopted by the U.S. Department of Energy [DOE] (10CFR part 850, 1999) and are updated to concur with any OSHA changes. The Nuclear Regulatory Commission (NRC)/EPA guideline for $\mathrm{U}$ for the general public is $0.18 \mu \mathrm{g} \mathrm{m}^{-3}$ in air (10 CFR part 20, Appendix B, 2003).

In this report, data for Be and $U$ in air at Illeginni Island will be compared to the more restrictive general public guidelines.

\section{Methods}

\section{Soils samples}

Because re-suspension of $\mathrm{U}$ and $\mathrm{Be}$ from surface soil is of primary concern, soil samples were collected in August
2005 from 0 to $5 \mathrm{~cm}$ depth at various grid locations that comprised the deposition area for a given mission (Figure 2). Soil samples were collected 


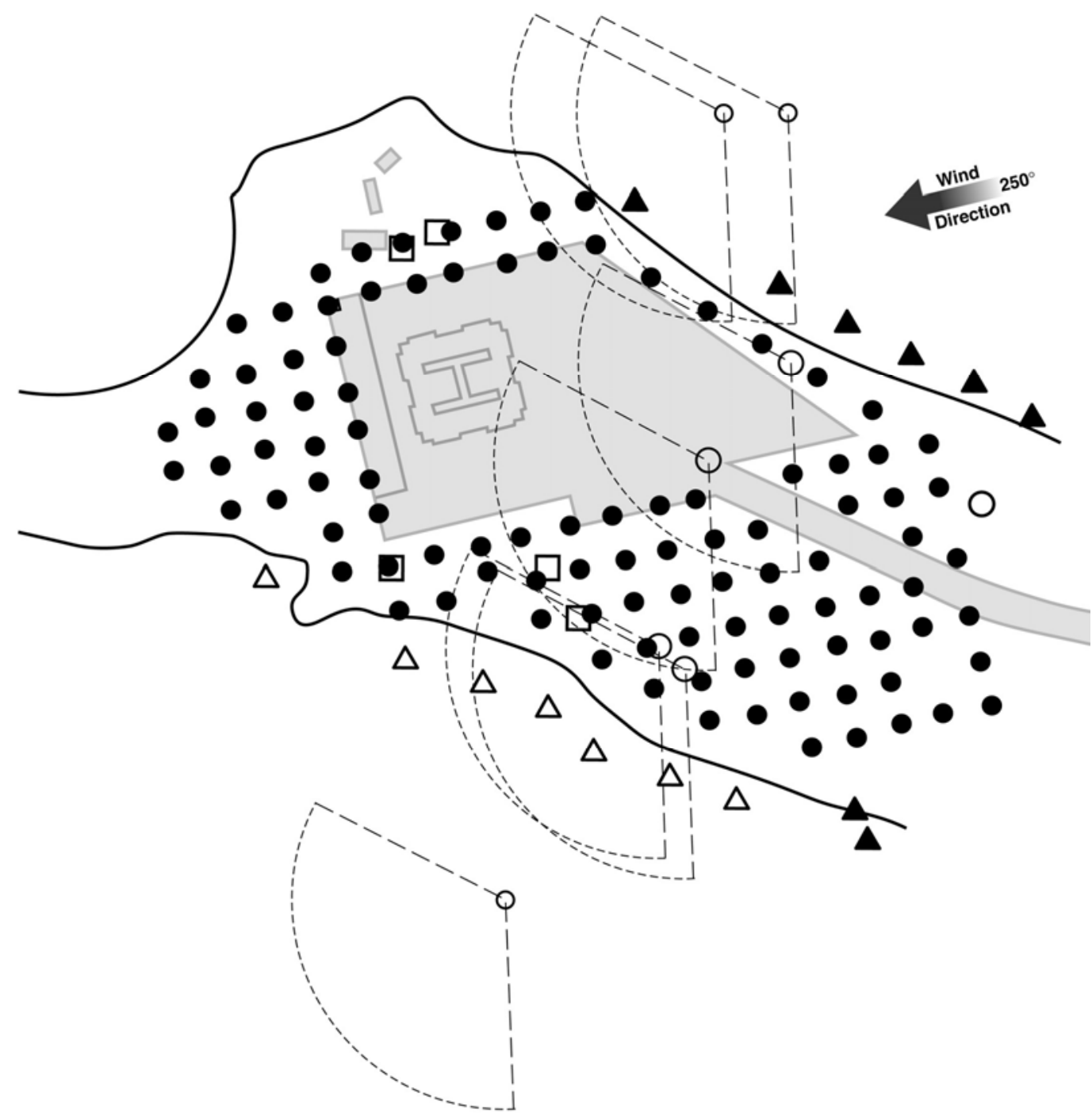

Figure 2. Map of the area on Illeginni Island where deposition of materials occurred. The round, open circles represent the impact point for those tests that deposited some U, Be, and coral on the island. The dashed lines indicate the angle that coral and RV materials were ejected upon impact. The open squares show the location of the hi-volume air samplers that were used to collect re-suspended surface soil to determine the concentration of $U$ and Be in air. All the air sampler sites are downwind of the major deposition areas. The solid and open triangles indicate the locations of marine sediments collected for analysis of $U$ and Be. Most of the impacts were in the deep ocean represented by the open circle and ejection angles off the island.

by digging a small trench about $40 \mathrm{~cm}$ long by $20 \mathrm{~cm}$ wide by $15 \mathrm{~cm}$ deep. A stainless steel tool, $15 \mathrm{~cm}$ by $15 \mathrm{~cm}$ by 5 $\mathrm{cm}$, was used to collect each 5 -cm soil sample; it was washed between sample collections to avoid any contamination from the previously collected sample. Each sample was put into a clean plastic 
bag, sealed, labeled, and shipped to LLNL for processing and analysis of $\mathrm{U}$ and Be.

Four soil profiles $(0-5 \mathrm{~cm}, 5-10 \mathrm{~cm}$, $10-15 \mathrm{~cm}$, and $15-20 \mathrm{~cm}$ ) were also collected to determine the depth distribution of $\mathrm{U}$ and $\mathrm{Be}$ in soil in the area of deposition. These samples were collected in a similar manner as the $0-5$ cm samples except a backhoe was used to dig a deeper and wider trench so that incremental profile samples could easily be collected without worrying about contamination of deeper samples from above layers of soil. Coordinates ( $\mathrm{X}$ axis first, $\mathrm{Y}$ axis second) of soil profile samples are 06, 05; 05.5, 05.5; 04.5, 05.5; and 05.5, 05.5. The location can be determined using Figure 3.

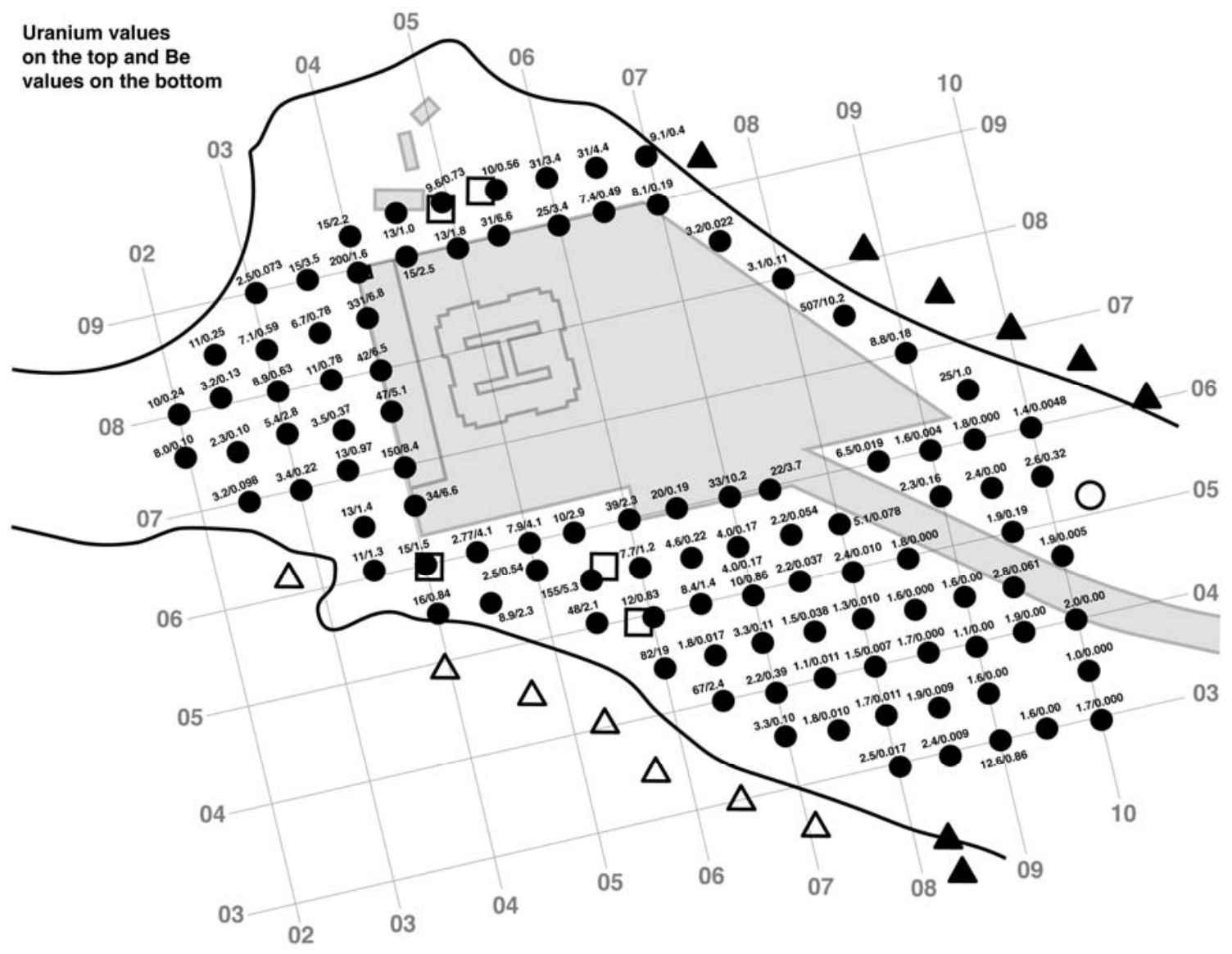

Figure 3. Illeginni Island grid with $\mathrm{U}$ and Be data at each sampling site. 
Bulk soils were prepared for chemical analysis by placing them in metal cans and drying them to constant weight in large convection ovens. Lids were placed on the cans and the dried material homogenized for 24-h by agitation on a rolling mill. Large chunks of hard coral soil and pebbles were removed prior to sample analysis by sieving samples through a 16-mesh (1.6 $\mathrm{mm}$ ) NBS screen.

Chemical analysis of soil samples was performed on 1-g aliquots of sample matrix placed in acid leached polypropylene digestion vessels along with $20 \mathrm{~g}$ of concentrated nitric acid and hydrogen peroxide mixture. Dissolution of sediment samples was completed by treating any residue with a combination of nitric and hydrofluoric acid. All samples were then evaporated to near dryness, re-hydrated in 2\% ultra-pure nitric acid, filtered through a $0.45 \mathrm{~mm}$ syringe-filter and diluted to a constant volume. Appropriate gravimetric dilutions were then prepared for chemical analysis by serial dilution of the stock digest.

Uranium and Be were measured by Inductively Coupled Plasma Mass Spectrometry (ICP-MS) with addition of 1 ppm of lithium-6 ( ${ }^{6} \mathrm{Li}$ ) (for Be analysis) and $1 \mathrm{ppb}$ of uranium-233 (233U) (for $U$ analysis) as internal standard. Control samples included blanks and approximately $10 \%$ of blind replicates prepared from the stock digest. A series of MAPEP (Mixed Analyte Performance Evaluation Program, an analytical performance testing program run by DOE), inter-comparison soils were also prepared and analyzed as quality control samples for the Be and $U$ analyses.

\section{Suspended Surface-Soil Samples (Air Filter Samples)}

Concentration of $U$ and Be in air were determined using high-volume air samplers running at approximately 60 $\mathrm{m}^{3} \mathrm{~h}^{-1}\left(2100 \mathrm{ft}^{3} \mathrm{~h}^{-1}\right)$ for a period of 30 to 40 days. The samplers are designed to collect the total suspended solids. There is no cut off at 10 to $20 \mu \mathrm{m}$ particle size that is the upper limit for particles that can be inhaled and deposited in the deep lung. Consequently, data for concentrations of soil in air in this report overestimate the respirable component that could reach the lung. Filters were exchanged after 2 weeks of continuous running to avoid overloading the filters. The amount of air passed through each Whatman 41 cellulose filter ranged from 10,000 to $22,000 \mathrm{~m}^{3} \quad(350,000$ to $\left.777,000 \mathrm{ft}^{3}\right)$. The total amount of air filtered over the 40-day sampling program was about 232,000 $\mathrm{m}^{3}$ $\left(8,180,000 \mathrm{ft}^{3}\right)$. Average TSP (total suspended particles) in air based on analysis of the filters was $54 \mathrm{mg} \mathrm{m}^{-3}$.

The filters were each dried (at $80^{\circ}$ C) and weighed then placed in a plastic bag that is sealed prior to transport to the field. The clean filters are placed in air samplers using surgeon gloves to avoid contamination of the filter. At the end of the sampling period, filters are collected, again using surgeon gloves, and placed in clean plastic bags for transport to LLNL.

Upon return to LLNL the filters were dried, weighed, dry-ashed and then analyzed for $U$ and Be. The ashing process starts at $100^{\circ} \mathrm{C}$ increasing by $100^{\circ} \mathrm{C}$ increments for 3 days to $400^{\circ} \mathrm{C}$. They are held at $400^{\circ} \mathrm{C}$ for $48 \mathrm{~h}$ at which time the ashed sample is allowed to slowly cool to room temperature. The ashed sample is then weighed. 
Dissolution and preparation for $\mathrm{U}$ and Be analysis of the ashed samples is the same as that described above for soils.

\section{Results}

Cumulative effects of the test program from 1990 to 2006 are presented in this report. Tests that produced some deposition of $\mathrm{U}$ and $\mathrm{Be}$ on Illeginni Island were GT02, 1990; GT10, 1992; GT17, 1995; GT22, 1996, and GT32, 2003. Impact locations on or near Illeginni Island and the normal wind direction are shown in Figure 2. Results for mean and median concentrations of $U$ and $\mathrm{Be}$ in surface soils in deposition areas on Illeginni Island are listed in Table 1 along with standard deviations and standard errors. The $U$ median value is $6.5 \mu \mathrm{g} \mathrm{g}^{-1}$ and for Be $0.22 \mu \mathrm{g} \mathrm{g}^{-1}$. These results are based on 105 samples collected in the deposition area of the island (Figure 3). $\mathrm{U}$ concentration is listed on top and Be concentration on the bottom at each soil sampling point (black dots). An additional 12 samples were obtained in the process of collecting four soil profiles. Concentration of $\mathrm{U}$ and $\mathrm{Be}$ outside the area represented by data shown in Figure 3 is essentially at the natural background concentration of $U$ and $\mathrm{Be}$ in coral soil, $1.6 \mathrm{mg} \mathrm{g}^{-1}$ and < $0.002 \mathrm{mg} \mathrm{g}^{-1}$, respectively (Robison et al., 2005).

Distribution with soil depth of $U$ and Be in four soil profiles in the
Illeginni deposition area is shown in Figures 4 and 5, respectively. There is a definite decline in concentration with depth and the concentration approaches background levels below 10-15 cm with one exception for each element. The $\mathrm{U}$ and Be concentration in each soil sample and replicate sample are listed in Appendix A along with coordinate positions shown in Figure 3.

As discussed above, the most important data refer to the concentration of $U$ and $B e$ in air because inhalation of $\mathrm{U}$ and $\mathrm{Be}$ is the critical exposure pathway. Results of the concentration of $\mathrm{U}$ and $\mathrm{Be}$ in air downwind of the deposition area at Illeginni as a function of time (missions) are shown in Figure 6. Concentration of both elements in air over the entire test period is about a factor of 10,000 lower than the most restrictive guideline for the general public. Uranium concentrations in air are also lower by factors of 10 to 100 than concentrations of $U$ in air in the U.S. measured by the EPA (Keith et al., 1999). $\mathrm{U}$ and Be concentrations in air downwind of the deposition areas on Illeginni Island are essentially indistinguishable from natural background concentrations of $\mathrm{U}$ in air at the atolls.

Table 1. Concentrations of $U$ and Be in Soil at Illeginni Island.

\begin{tabular}{lcc}
\hline & $\mathbf{U}, \boldsymbol{\mu} \mathbf{g ~ g}^{-\mathbf{1}}$ & $\mathbf{B e}, \boldsymbol{\mu} \mathbf{g ~ g}^{-\mathbf{1}}$ \\
\hline Median & 6.5 & 0.22 \\
Mean & 24 & 1.6 \\
Standard Deviation & 6.6 & 3.4 \\
Standard Error & 6.1 & 0.32 \\
Number & 117 & 117 \\
\hline
\end{tabular}




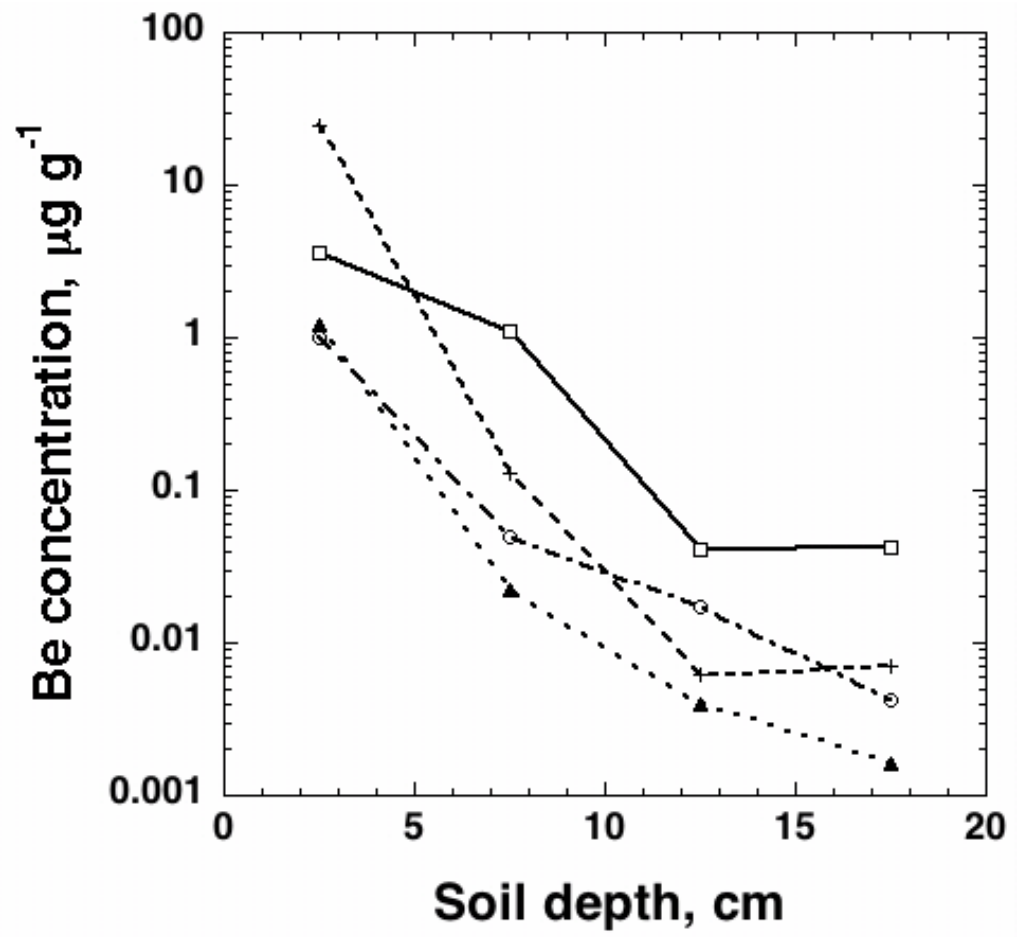

Figure 4. Beryllium concentration versus depth in soil profiles on Illeginni Island.

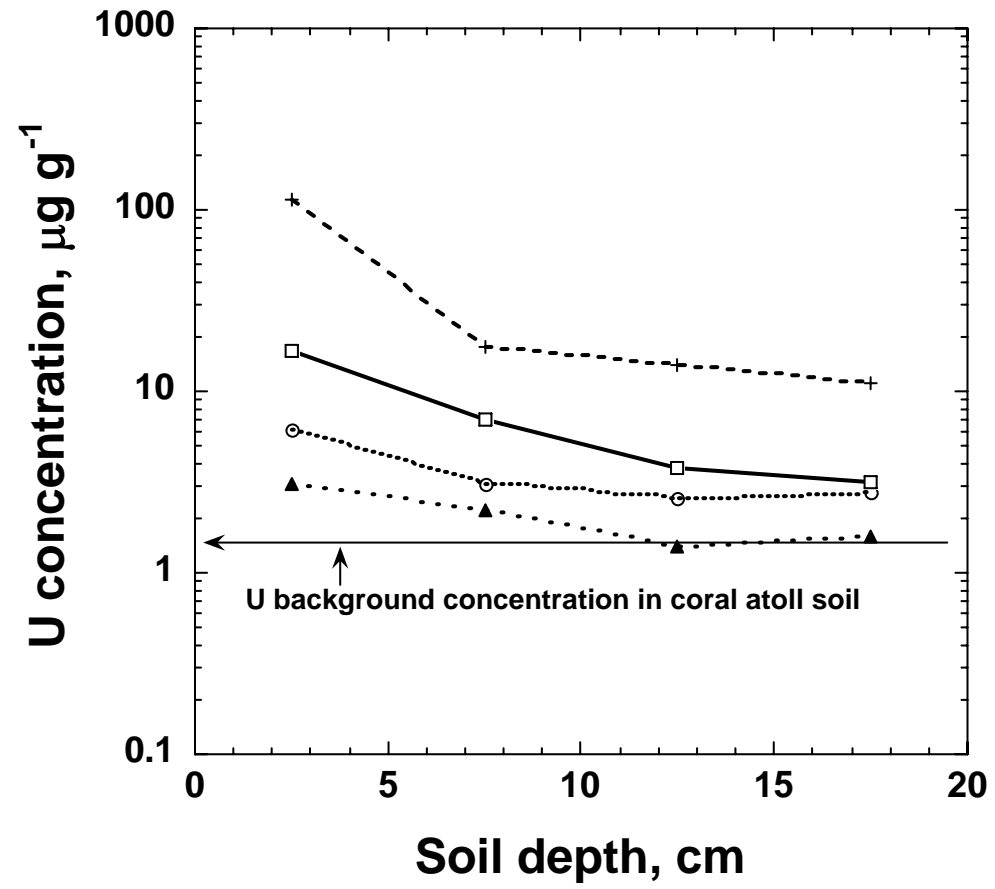

Figure 5. Uranium concentration versus depth in soil profiles on Illeginni Island. 


\section{Discussion}

DU and Be from the missile flight test program is deposited over a small section of land on Illeginni Island near the helipad at the northwest end of the island (compare Figure 2 deposition area around the helipad with Figure 1 showing the entire island). Concentrations of $\mathrm{U}$ and $\mathrm{Be}$ in air downwind of the deposition area are lower by a factor of 10,000 than the most restrictive U.S. federal guideline for the general public. Even so, the amount of re-suspended particulates containing $\mathrm{U}$ and $\mathrm{Be}$ can be expected to further decrease as vegetation redevelops in the deposition area reducing the amount of wind-driven re-suspended particulates from soil surface.

Moreover, air samplers used to collect re-suspended soil particulates to measure the $\mathrm{U}$ and $\mathrm{Be}$ concentrations are designed to collect total suspended particulates (TSP). This means particle sizes up to $50 \mu \mathrm{m}$ or more are collected. The particle size upper limit for entering the deep lung where $\mathrm{U}$ and Be could be lodged or transferred to the blood is between 10 and $20 \mu \mathrm{m}$. Thus, TSP we measure on our filters is really an overestimate of what can really be deposited in the deep lung and any $\mathrm{U}$ or Be attached to such particles would not be transferred to the blood stream. Consequently, concentrations of $U$ and Be shown in Figure 6 are very conservation.

Analysis of soil profile samples for $\mathrm{U}$ and Be show some distribution with depth from 1990 to 2006. Some of the distribution below the top $5 \mathrm{~cm}$ of soil could be due to mechanical disturbance between successive missions. But rainfall, flooding, and general weathering processes can also distribute fine particles of $U$ and $\mathrm{Be}$, or fine soil particles containing DU and Be, deeper into the soil profile. In either case, the amount of DU-Be-containing particles of respirable size in surface soil will likely decrease somewhat with time due to both processes.

There are guidelines in the U.S. for $\mathrm{U}$ in drinking water but they are in the $\mathrm{mg} \mathrm{L}^{-1}$ range. Any DU or Be that might possibly be transported to the Illeginni ground water that is about $3 \mathrm{~m}$ below the ground surface would be in the ng $\mathrm{L}^{-1}$ or pg L ${ }^{-1}$ range (1 million to 1 billion times lower than the drinking water standards). Furthermore, the ground water at the northwest end of the island where DU and Be deposition occurred is saline and not potable. If some DU and Be should reach the ground water on Illeginni in soluble form it will communicate with the ocean waters and be indistinguishable from world wide background concentrations of $\mathrm{U}$ and $\mathrm{Be}$ in the ocean.

Concentration of DU and Be is at background concentrations at gridline 9 and 10 on the $X$ axis up to gridline 6 on the $\mathrm{Y}$ axis in Figure 3. The rest of the island to the right of gridline 10 on the $\mathrm{X}$ axis (down the road leading to the rest of the island) has background concentrations of $U$ and $B e$ in the soil. To the left of gridline 1 on the $\mathrm{X}$ axis (not shown on Figure 3 ) the $\mathrm{U}$ and $\mathrm{Be}$ concentrations in soil are essentially at background concentrations. Thus, data displayed in Figure 3 does define the contaminated portion of Ileginni Island.

The larger quantities of DU and Be deposited in the ocean have no significant impact on marine flora and fauna nor on humans as a result of their insolubility in sea water as described in the Background section of this paper. 


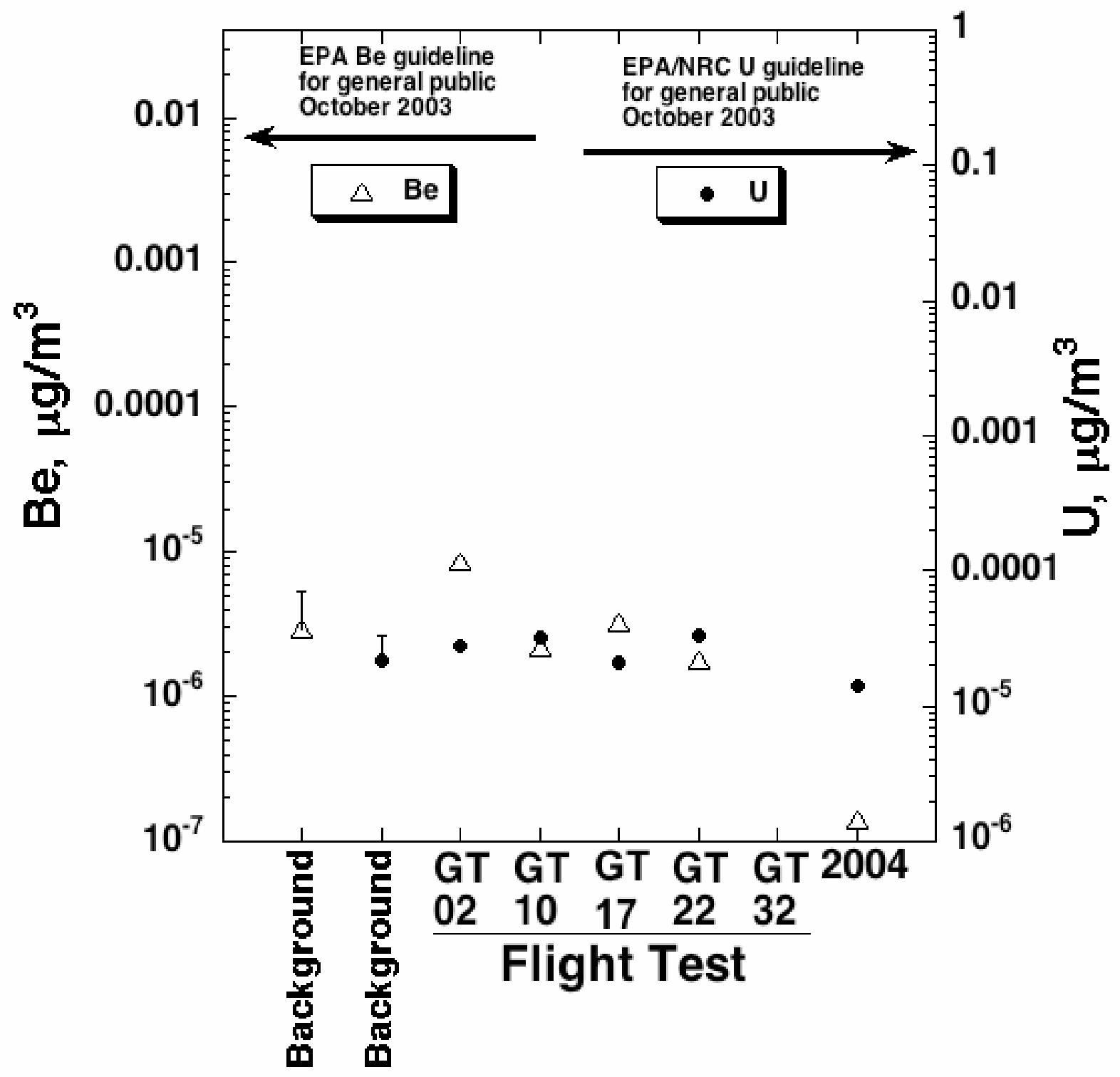

Figure 6. The concentration of $U$ and Be in air at Illeginni Island. The upper error bars (1 standard deviation) are shown for the series of $U$ and Be background measurements.

\section{Conclusion}

The critical route of exposure for $U$ and Be at Illeginni Island is inhalation as these two materials are distributed on the soil surface. Measured concentrations of $\mathrm{U}$ and $\mathrm{Be}$ in air down wind of the deposition area are lower by a factor of 10,000 than the most restrictive U.S. federal guidelines for the general public. Also, concentrations of $U$ in air at Illeginni are less by a factor of 10 to 100 
than $U$ concentrations in air in the U.S. measured by the EPA (Keith et al., 1999) and they are indistinguishable from natural background concentrations of $\mathrm{U}$ and $\mathrm{Be}$ in air at the atolls. Thus, there are no health related issues associated with people using the island.

Concentrations of $U$ and $B e$ in soil in the relatively small deposition areas of the island do exceed the natural background concentrations in coral atoll soils. But because of the chemical and structural form of $\mathrm{U}$ and $\mathrm{Be}$ in the RVs they are insoluble in sea water and ground water. Thus, as described in this paper, there is neither an effect on island plants or animals nor on the marine flora and fauna as a result of the missile flight tests.

\section{Acknowledgements}

This work was performed under the auspices of the U. S. Department of Energy by the University of California, Lawrence Livermore National Laboratory under Contract No. W-7405-Eng-48.

\section{Units Used}

1 part per thousand

$=1$ milligram $\mathrm{g}^{-1}$

$=1 \mathrm{mg} \mathrm{g}^{-1}=10^{-3} \mathrm{~g} \mathrm{~g}^{-1}$

$=0.001 \mathrm{~g} \mathrm{~g}^{-1}$

1 part per million

$=1$ microgram $\mathrm{g}^{-1}$

$=1 \mu \mathrm{g} \mathrm{g}^{-1}=10^{-6} \mathrm{~g} \mathrm{~g}^{-1}$

$=0.000001 \mathrm{~g} \mathrm{~g}^{-1}$
1 part per billion

$=1$ nanogram $\mathrm{g}^{-1}$

$=1 \mathrm{ng} \mathrm{g}^{-1}=10^{-9} \mathrm{~g} \mathrm{~g}^{-1}$

$=0.000000001 \mathrm{~g} \mathrm{~g}^{-1}$

1 part per trillion

$=1$ picogram $\mathrm{g}^{-1}$

$=1 \mathrm{pg} \mathrm{g}^{-1}=10^{-12} \mathrm{~g} \mathrm{~g}^{-1}$

$=0.000000000001 \mathrm{~g} \mathrm{~g}^{-1}$ 


\section{References}

Assimakopoulos, P., (2003), Editoral, Journal of Environmental Radioactivity, 64 No. 2-3, Special Issue, Depleted Uranium.

Bleise, A., P. R. Danesi, and W. Burkart, (2003), Properties, use and health effects of depleted uranium (DU): a general overview, Journal of Environmental Radioactivity, 64 No. 2-3, 93-112.

Durante, M., and M. Pugliese, (2002), Estimates of Radiological Risk from Depleted uranium Weapons in War Scenarios, Health Physics, 82, No. 1, 1420.

Keith, M., W. Spoo, J. Corocoron, (1999), Toxicological profile for uranium (update), ASTDR, U.S. Department of Health and Human Services, Atlanta GA.

Meinrath, A., P.Schneider, and G. meinrath, (2003), Uranium ores and depleted uranium in the environment, with a reference to uranium in the biosphere from the Erzgebirge/Sachsen, Germany, Journal of Environmental Radioactivity, 64 No. 2-3, 175-193.

McCright, D., (1996), Corrosion of U in Sea Water. Lawrence Livermore National Laboratory, Internal Report, Livermore, CA, Official Use Only.

McDiarmid, M., K. Squibb, and S.Englehardt, (2004), Biologic Monitoring for Urinary Uranium In Gulf War I veterans, Health Physics, 87 No. 1, 51-56.
Robison, W. L. and J. H. Shinn, (1988), Environmental Assessment: ReEntry Vehicle Impact Dispersing Beryllium and Depleted Uranium, Illeginni Island, Government of the Republic of the Marshall Islands, Lawrence Livermore National Laboratory report, Livermore CA, UCAR-10260, Distribution limited.

Robison, W. L. and J. H. Shinn, (1990), The Concentrations of Be and DU in the air and soil at Illeginni Island after completion of the JTA-301 Mission, Lawrence Livermore National Laboratory report, Livermore, CA, UCRL-AR-104919, Controlled Distribution, Official Use Only.

Robison, W. L. and R. Cederwall, (1992), Environmental Assessment: DOE Re-entry Vehicle, Flight Test Program United States Army Kwajalein Atoll Republic of the Marshall Islands, Lawrence Livermore National Laboratory report, Livermore, CA, COMW-91-1043-Revision 3.

Robison, W. L., (1992), The Distribution and Resuspension of Be and $\mathrm{U}$ at Kwajalein Atoll Subsequent to the GT10 and GT149 Missions in September 1992, Lawrence Livermore National Laboratory report, Livermore, CA, UCRL-ID-119110. Controlled Distribution. 
Robison, W. L., T. F. Hamilton, R. E. Martinelli, S. R. Kehl, T. R. Lindman (2005), Concentration of Beryllium (Be) and Depleted Uranium (DU) in Marine Fauna and Sediment Samples from Illeginni and Boggerik Islands at Kwajalein Atoll, Lawrence Livermore National Laboratory report, Livermore, CA, UCRL-TR-210057.
Shinn, J. H., L. A. Sharmer, R. T. Cederwall,M. G. Novo, C. S. Mitchell, (1988), Report on Environmental Effects at Yuma Proving Ground from Continued Testing of Projectiles Containing Beryllium and Depleted Uranium, Lawrence Livermore National Laboratory report, Livermore CA, UCID-21277.

USAF (2004), Environmental Assessment for Minuteman III Modification. 


\section{Appendix A}

Uranium and Be concentration in all soil samples from Illeginni Island at Kwajalein Atoll. 
Table A-1. Uranium and Be concentration in all soil samples from Illeginni Island at Kwajalein Atoll.

\begin{tabular}{|c|c|c|c|c|c|c|}
\hline Soil Sample Identification & $\begin{array}{c}\text { Mean U } \\
\text { mg }^{-1}\end{array}$ & Mean U mg m $^{-1}$ & $\mathbf{U}$ & $\begin{array}{c}\text { Mean Be } \\
\text { mg }^{-1}\end{array}$ & Mean Be $\mathrm{mg}^{-1}$ & Be \\
\hline Soil depth: grid location & dry wt. & dry wt. & Stdev & dry wt. & dry wt. & Stdev \\
\hline $0-5 \mathrm{~cm} ; 02,08$ & 10.3 & & & 0.21 & & \\
\hline Blind Replicate Sample & 9.7 & 10.0 & 0.44 & 0.26 & 0.24 & 0.04 \\
\hline $0-5 \mathrm{~cm} ; 03,08$ & 8.9 & 8.9 & & 0.63 & 0.63 & \\
\hline $0-5 \mathrm{~cm} ; 02.5,08$ & 3.2 & 3.2 & & 0.13 & 0.13 & \\
\hline $0-5 \mathrm{~cm} ; 02,07.5$ & 8.3 & & & 0.13 & & \\
\hline Blind Replicate Sample & 7.6 & 8.0 & 0.53 & 0.071 & 0.10 & 0.038 \\
\hline $0-5 \mathrm{~cm} ; 02.5,07$ & 3.2 & 3.2 & & 0.098 & 0.098 & \\
\hline $0-5 \mathrm{~cm} ; 03,07$ & 3.4 & 3.4 & & 0.22 & 0.22 & \\
\hline $0-5 \mathrm{~cm} ; 03,07.5$ & 5.4 & 5.4 & & 0.28 & 0.28 & \\
\hline $0-5 \mathrm{~cm} ; 03,09$ & 2.7 & & & 0.079 & & \\
\hline Blind Replicate Sample & 2.2 & 2.5 & 0.35 & 0.067 & 0.073 & 0.009 \\
\hline $0-5 \mathrm{~cm} ; 03,08.5$ & 7.1 & 7.1 & & 0.59 & 0.59 & \\
\hline 0-5 cm; 04, 09 & 730 & & & 1.4 & & \\
\hline Blind replicate sample & 24 & & & 2.0 & & \\
\hline Blind replicate sample & 23 & & & 1.5 & & \\
\hline Blind replicate sample & 24 & 200 & 353 & 1.4 & 1.6 & 0.24 \\
\hline $0-5 \mathrm{~cm} ; 04,08.5$ & 304 & & & 9.6 & & \\
\hline Blind replicate sample & 355 & & & 8.8 & & \\
\hline Blind replicate sample & 265 & & & 4.8 & & \\
\hline Blind replicate sample & 347 & & & 5.1 & & \\
\hline Blind replicate sample & 383 & 331 & 47 & 6.0 & 6.8 & 2.2 \\
\hline $0-5 \mathrm{~cm} ; 04,09.2$ & 15.4 & 15.4 & & 2.2 & 2.2 & \\
\hline $0-5 \mathrm{~cm} ; 04,08$ & 42.8 & & & 4.7 & & \\
\hline Blind replicate sample & 43.4 & & & 4.6 & & \\
\hline Blind replicate sample & 41.0 & & & 11.3 & & \\
\hline Blind replicate sample & 41.9 & 42.3 & 1.0 & 5.2 & 6.5 & 3.2 \\
\hline $0-5 \mathrm{~cm} ; 04,07.5$ & 45.3 & & & 8.5 & & \\
\hline Blind Replicate Sample & 28.5 & & & 4.3 & & \\
\hline Blind Replicate Sample & 56.1 & & & 4.5 & & \\
\hline Blind Replicate Sample & 53.4 & & & 4.6 & & \\
\hline Blind Replicate Sample & 52.1 & 47.1 & 11 & 3.8 & 5.1 & 1.9 \\
\hline $0-5 \mathrm{~cm} ; 04,07$ & 138 & & & 7.27 & & \\
\hline Blind Replicate Sample & 177 & & & 8.9 & & \\
\hline Blind Replicate Sample & 124 & & & 4.6 & & \\
\hline Blind Replicate Sample & 146 & & & 7.1 & & \\
\hline Blind Replicate Sample & 160 & & & 5.8 & & \\
\hline Blind Replicate Sample & 155 & 150 & 19 & 16.9 & 8.4 & 4.4 \\
\hline $0-5 \mathrm{~cm} ; 04,06.5$ & 34.0 & & & 7.2 & & \\
\hline Blind Replicate Sample & 32.1 & & & 7.6 & & \\
\hline Blind Replicate Sample & 41.9 & & & 7.0 & & \\
\hline Blind Replicate Sample & 30.7 & 34.7 & 5.0 & 4.7 & 6.6 & 1.3 \\
\hline $0-5 \mathrm{~cm} ; 04,06$ & 15.0 & 15.0 & & 1.5 & 1.5 & \\
\hline $0-5 \mathrm{~cm} ; 04,05.6$ & 16.0 & 16.0 & & 0.84 & 0.84 & \\
\hline $0-5 \mathrm{~cm} ; 03.5,06$ & 13.4 & & & 1.4 & & \\
\hline Blind Replicate Sample & 7.7 & 10.6 & 4.0 & 1.2 & 1.3 & 0.16 \\
\hline $0-5 \mathrm{~cm} ; 03.5,07$ & 13.2 & 13.2 & & 0.97 & 0.97 & \\
\hline $0-5 \mathrm{~cm} ; 03.5,08$ & 10.5 & 10.5 & & 0.78 & 0.78 & \\
\hline $0-5 \mathrm{~cm} ; 03.5,09$ & 15.2 & 15.2 & & 3.5 & 3.5 & \\
\hline $0-5 \mathrm{~cm} ; 04.5,09$ & 14.6 & 14.6 & & 2.5 & 2.5 & \\
\hline $0-5 \mathrm{~cm} ; 05,09$ & 13.1 & 13.1 & & 1.8 & 1.8 & \\
\hline $0-5 \mathrm{~cm} ; 05.5,09$ & 32.9 & & & 5.5 & & \\
\hline Blind Replicate Sample & 28.7 & & & 7.2 & & \\
\hline Blind Replicate Sample & 26.8 & & & 5.3 & & \\
\hline Blind Replicate Sample & 37.1 & 31.4 & 4.6 & 8.4 & 6.6 & 1.5 \\
\hline $0-5 \mathrm{~cm} ; 06,09$ & 24.7 & 24.7 & & 3.4 & 3.4 & \\
\hline $0-5 \mathrm{~cm} ; 06.5,09$ & 7.4 & 7.4 & & 0.49 & 0.49 & \\
\hline $0-5 \mathrm{~cm} ; 07,09$ & 8.1 & 8.1 & & 0.19 & 0.19 & \\
\hline $0-5 \mathrm{~cm} ; 07,09.2$ & 9.1 & 9.1 & & 0.4 & 0.4 & \\
\hline $0-5 \mathrm{~cm} ; 04.5,09.4$ & 13.1 & 13.1 & & 1.0 & 1.0 & \\
\hline $0-5 \mathrm{~cm} ; 05,09.5$ & 9.6 & 9.6 & & 0.73 & 0.73 & \\
\hline
\end{tabular}


Table A-1. Continued.

\begin{tabular}{|c|c|c|c|c|c|c|}
\hline $0-5 \mathrm{~cm} ; 05.5,09.5$ & 10.1 & 10.1 & & 0.56 & 0.56 & \\
\hline $0-5 \mathrm{~cm} ; 06,09.7$ & 33.6 & & & 4.5 & & \\
\hline Blind Replicate Sample & 23.4 & & & 2.3 & & \\
\hline Blind Replicate Sample & 44.5 & & & 4.1 & & \\
\hline Blind Replicate Sample & 23.2 & 31.2 & 10 & 2.6 & 3.4 & 1.1 \\
\hline $0-5 \mathrm{~cm} ; 06.5,09.5$ & 26.5 & & & 2.3 & & \\
\hline Blind Replicate Sample & 38.8 & & & 6.2 & & \\
\hline Blind Replicate Sample & 30.8 & & & 5.0 & & \\
\hline Blind Replicate Sample & 28.5 & 31.2 & 5.4 & 4.1 & 4.4 & 1.6 \\
\hline $0-5 \mathrm{~cm} ; 07.5,08.5$ & 3.2 & 3.2 & & 0.022 & 0.022 & \\
\hline $0-5 \mathrm{~cm} ; 08,08$ & 3.1 & 3.1 & & 0.11 & 0.11 & \\
\hline $0-5 \mathrm{~cm} ; 08.5,07.5$ & 315 & & & 7.3 & & \\
\hline Blind Replicate Sample & 473 & & & 15.3 & & \\
\hline Blind Replicate Sample & 519 & & & 7.3 & & \\
\hline Blind Replicate Sample & 494 & & & 12.9 & & \\
\hline Blind Replicate Sample & 545 & 507 & 90 & 8.2 & 10.2 & 3.7 \\
\hline $0-5 \mathrm{~cm} ; 09,07$ & 8.8 & 8.8 & & 0.18 & 0.18 & \\
\hline $0-5 \mathrm{~cm} ; 09.5,06.5$ & 25.3 & 25.3 & & 1.0 & 1.0 & \\
\hline $0-5 \mathrm{~cm} ; 10,06$ & 1.6 & & & 0.000 & & \\
\hline Blind Replicate Sample & 1.0 & & & 0.020 & & \\
\hline Blind Replicate Sample & 1.6 & & & 0.00049 & & \\
\hline Blind Replicate Sample & 1.3 & & & 0.00050 & & \\
\hline Blind Replicate Sample & 1.2 & 1.4 & 0.27 & 0.00049 & 0.0043 & 0.0089 \\
\hline $0-5 \mathrm{~cm} ; 10,05.5$ & 2.6 & 2.6 & & 0.032 & 0.032 & \\
\hline $0-5 \mathrm{~cm} ; 10,04.5$ & 1.9 & 1.9 & & 0.005 & 0.005 & \\
\hline $0-5 \mathrm{~cm} ; 10,04$ & 2.0 & 2.0 & & 0.000 & 0.000 & \\
\hline $0-5 \mathrm{~cm} ; 10,03.5$ & 1.0 & 1.0 & & -0.001 & -0.001 & \\
\hline $0-5 \mathrm{~cm} ; 10,03$ & 1.7 & 1.7 & & -0.001 & -0.001 & \\
\hline $0-5 \mathrm{~cm} ; 09.5,06$ & 1.8 & & & -0.001 & & \\
\hline Blind Replicate Sample & 1.5 & 1.6 & 0.24 & 0.009 & 0.0039 & 0.0073 \\
\hline $0-5 \mathrm{~cm} ; 09.3,05.5$ & 2.4 & 2.4 & & -0.001 & -0.001 & \\
\hline $0-5$ cm; 09.5, 05 & 2.3 & & & 0.010 & & \\
\hline Blind Replicate Sample & 1.5 & 1.9 & 0.53 & 0.029 & 0.019 & 0.013 \\
\hline $0-5 \mathrm{~cm} ; 09.5,04.5$ & 2.8 & & & 0.053 & & \\
\hline Blind Replicate Sample & 2.8 & 2.8 & & 0.070 & 0.061 & 0.012 \\
\hline $0-5 \mathrm{~cm} ; 09.5,04$ & 1.4 & 1.4 & & -0.001 & -0.001 & \\
\hline $0-5 \mathrm{~cm} ; 09.5,03$ & 1.4 & & & -0.005 & & \\
\hline Blind Replicate Sample & 1.7 & 1.6 & 0.23 & 0.002 & -0.001 & 0.0055 \\
\hline $0-5 \mathrm{~cm} ; 09,06$ & 11.6 & 11.6 & & 0.086 & 0.086 & \\
\hline $0-5 \mathrm{~cm} ; 09,05.5$ & 2.3 & 2.3 & & 0.016 & 0.016 & \\
\hline $0-5 \mathrm{~cm} ; 09,04.5$ & 1.6 & 1.6 & & -0.001 & -0.001 & \\
\hline $0-5 \mathrm{~cm} ; 09,04$ & 1.1 & 1.1 & & -0.001 & -0.001 & \\
\hline $0-5 \mathrm{~cm} ; 09,03.5$ & 1.6 & 1.6 & & -0.001 & -0.001 & \\
\hline $0-5 \mathrm{~cm} ; 08.5,06$ & 6.5 & 6.5 & & 0.192 & 0.192 & \\
\hline $0-5 \mathrm{~cm} ; 08.5,05$ & 1.8 & & & -0.001 & & \\
\hline Blind Replicate Sample & 2.0 & & & 0.00050 & & \\
\hline Blind Replicate Sample & 1.8 & & & 0.00049 & & \\
\hline Blind Replicate Sample & 1.8 & 1.8 & 0.088 & 0.00049 & 0.00008 & 0.0008 \\
\hline $0-5 \mathrm{~cm} ; 08.5,04.5$ & 1.6 & 1.6 & & -0.005 & -0.005 & \\
\hline $0-5 \mathrm{~cm} ; 08.5,04$ & 1.7 & 1.7 & & -0.001 & -0.001 & \\
\hline $0-5 \mathrm{~cm} ; 08.5,03.5$ & 1.9 & 1.9 & & 0.009 & 0.009 & \\
\hline $0-5 \mathrm{~cm} ; 08.5,03$ & 2.4 & 2.4 & & 0.009 & 0.009 & \\
\hline $0-5 \mathrm{~cm} ; 08,05.5$ & 5.1 & 5.1 & & 0.078 & 0.078 & \\
\hline $0-5 \mathrm{~cm} ; 08,05$ & 2.4 & 2.4 & & 0.010 & 0.010 & \\
\hline $0-5 \mathrm{~cm} ; 08,04.5$ & 1.7 & & & 0.009 & & \\
\hline Blind Replicate Sample & 0.85 & 1.3 & 0.64 & 0.012 & 0.010 & 0.0018 \\
\hline $0-5$ cm; 08, 04 & 1.5 & 1.5 & & 0.007 & 0.007 & \\
\hline $0-5 \mathrm{~cm} ; 08,03.5$ & 1.7 & 1.7 & & 0.011 & 0.011 & \\
\hline $0-5 \mathrm{~cm} ; 08,03$ & 2.5 & 2.5 & & 0.017 & 0.017 & \\
\hline $0-5 \mathrm{~cm} ; 07.5,06$ & 22.1 & 22.1 & & 3.729 & 3.729 & \\
\hline $0-5 \mathrm{~cm} ; 07.5,05.5$ & 2.2 & & & 0.059 & & \\
\hline Blind Replicate Sample & 2.3 & 2.2 & 0.056 & 0.050 & 0.054 & 0.0060 \\
\hline $0-5 \mathrm{~cm} ; 07.5,05$ & 2.2 & 2.2 & & 0.037 & 0.037 & \\
\hline $0-5 \mathrm{~cm} ; 07.5,04.5$ & 1.6 & & & 0.014 & & \\
\hline
\end{tabular}


Table A-1. Continued.

\begin{tabular}{|c|c|c|c|c|c|c|}
\hline Blind Replicate Sample & 1.4 & & & 0.00049 & & \\
\hline Blind Replicate Sample & 1.6 & & & 0.00050 & & \\
\hline Blind Replicate Sample & 1.5 & 1.5 & & 0.00050 & 0.0038 & 0.0066 \\
\hline $0-5 \mathrm{~cm} ; 07.5,04$ & 1.4 & & & 0.011 & & \\
\hline Blind Replicate Sample & 0.7 & 1.1 & 0.53 & 0.011 & 0.011 & 0 \\
\hline $0-5 \mathrm{~cm} ; 07.5,03.5$ & 2.3 & & & 0.010 & & \\
\hline Blind Replicate Sample & 1.3 & 1.8 & 0.72 & 0.010 & 0.010 & 0 \\
\hline $0-5 \mathrm{~cm} ; 07,06$ & 46.5 & & & 29.4 & & \\
\hline Blind Replicate Sample & 31.9 & & & 7.0 & & \\
\hline Blind Replicate Sample & 31.7 & & & 7.5 & & \\
\hline Blind Replicate Sample & 32.6 & & & 6.6 & & \\
\hline Blind Replicate Sample & 28.2 & & & 4.8 & & \\
\hline Blind Replicate Sample & 28.8 & 33.3 & 6.7 & 6.0 & 10.2 & 9.4 \\
\hline $0-5 \mathrm{~cm} ; 07,05.5$ & 5.5 & & & 0.22 & & \\
\hline Blind Replicate Sample & 2.5 & 4.0 & 2.1 & 0.11 & 0.17 & 0.080 \\
\hline $0-5 \mathrm{~cm} ; 07,05$ & 10.0 & 10.0 & & 0.86 & 0.86 & \\
\hline $0-5 \mathrm{~cm} ; 07,04.5$ & 3.3 & 3.3 & & 0.11 & 0.11 & \\
\hline $0-5 \mathrm{~cm} ; 07,04$ & 2.2 & 2.2 & & 0.039 & 0.039 & \\
\hline $0-5 \mathrm{~cm} ; 07,03.5$ & 3.3 & 3.3 & & 0.10 & 0.10 & \\
\hline $0-5 \mathrm{~cm} ; 06.5,06$ & 19.5 & 19.5 & & 1.9 & 1.9 & \\
\hline $0-5 \mathrm{~cm} ; 06.5,05.5$ & 4.6 & 4.6 & & 0.22 & 0.22 & \\
\hline $0-5 \mathrm{~cm} ; 06.5,05$ & 8.4 & 8.4 & & 1.4 & 1.4 & \\
\hline $0-5 \mathrm{~cm} ; 06.5,04.5$ & 1.8 & 1.8 & & 0.017 & 0.017 & \\
\hline $0-5 \mathrm{~cm} ; 06.5,04$ & 68.7 & & & 1.93 & & \\
\hline Blind Replicate Sample & 67.5 & & & 2.00 & & \\
\hline Blind Replicate Sample & 70.1 & & & 2.15 & & \\
\hline Blind Replicate Sample & 64.3 & & & 2.82 & & \\
\hline Blind Replicate Sample & 66.3 & 67.4 & 2.2 & 3.20 & 2.4 & 0.56 \\
\hline $0-5 \mathrm{~cm} ; 06,06$ & 67.9 & & & 1.87 & & \\
\hline Blind Replicate Sample & 33.7 & & & 2.00 & & \\
\hline Blind Replicate Sample & 31.8 & & & 2.27 & & \\
\hline Blind Replicate Sample & 32.1 & & & 2.96 & & \\
\hline Blind Replicate Sample & 31.6 & 39.4 & 16 & 2.43 & 2.3 & 0.43 \\
\hline $0-5 \mathrm{~cm} ; 06,05.5$ & 7.7 & 7.7 & & 1.19 & 1.2 & \\
\hline $0-5 \mathrm{~cm} ; 06,05$ & 12.4 & 12.4 & & 0.83 & 0.83 & \\
\hline $0-5 \mathrm{~cm} ; 06,04.5$ & 83.2 & & & 16.8 & & \\
\hline Blind Replicate Sample & 78.6 & & & 17.9 & & \\
\hline Blind Replicate Sample & 80.5 & & & 20.6 & & \\
\hline Blind Replicate Sample & 85.1 & & & 20.0 & & \\
\hline Blind Replicate Sample & 84.2 & 82.3 & 2.7 & 20.5 & 19.2 & 1.7 \\
\hline $0-5 \mathrm{~cm} ; 05.5,06$ & 12.9 & & & 2.7 & & \\
\hline Blind Replicate Sample & 7.6 & 10.2 & 3.7 & 3.1 & 2.9 & 0.30 \\
\hline $0-5 \mathrm{~cm} ; 05.5,05.5$ & 543 & & & 0.55 & & \\
\hline Blind Replicate Sample & 82 & & & 0.59 & & \\
\hline Blind Replicate Sample & 102 & & & 0.56 & & \\
\hline Blind Replicate Sample & 68 & & & 0.52 & & \\
\hline Blind Replicate Sample & 62 & & & 0.43 & & \\
\hline Blind Replicate Sample & 73 & 155 & 190 & 0.53 & 0.53 & 0.055 \\
\hline $0-5 \mathrm{~cm} ; 05.5,05$ & 23.6 & & & 4.0 & & \\
\hline Blind Replicate Sample & 77.7 & & & 2.1 & & \\
\hline Blind Replicate Sample & 47.0 & & & 1.6 & & \\
\hline Blind Replicate Sample & 46.8 & & & 1.5 & & \\
\hline Blind Replicate Sample & 46.6 & 48.3 & 19 & 1.6 & 2.1 & 1.0 \\
\hline 005,06 & 7.9 & 7.9 & & 4.1 & 4.1 & \\
\hline $0-5 \mathrm{~cm} ; 05,05.5$ & 2.5 & 2.5 & & 0.54 & 0.54 & \\
\hline $0-5 \mathrm{~cm} ; 04.5,06$ & 308 & & & 6.4 & & \\
\hline Blind Replicate Sample & 298 & & & 3.6 & & \\
\hline Blind Replicate Sample & 274 & & & 3.3 & & \\
\hline Blind Replicate Sample & 247 & & & 2.8 & & \\
\hline Blind Replicate Sample & 268 & & & 4.4 & & \\
\hline Blind Replicate Sample & 267 & 277 & 22 & 4.3 & 4.1 & 1.3 \\
\hline $0-5 \mathrm{~cm} ; 04.5,05.5$ & 8.9 & 8.9 & & 2.3 & 2.3 & \\
\hline $0-5 \mathrm{~cm} ; 03.5,06.5$ & 13.1 & 13.1 & & 1.4 & 1.4 & \\
\hline $0-5 \mathrm{~cm} ; 03.5,07.5$ & 3.5 & 3.5 & & 0.37 & 0.37 & \\
\hline
\end{tabular}


Table A-1. Continued.

\begin{tabular}{|c|c|c|c|c|c|c|}
\hline $0-5 \mathrm{~cm} ; 03.5,08.5$ & 6.7 & 6.7 & & 0.78 & 0.78 & \\
\hline $0-5 \mathrm{~cm} ; 02.5,08.5$ & 10.8 & 10.8 & & 0.25 & 0.25 & \\
\hline $0-5 \mathrm{~cm} ; 02.5,07.5$ & 2.3 & 2.3 & & 0.10 & 0.10 & \\
\hline $0-5$ cm; 06, 05 & 6.1 & 6.1 & & 1.0 & 1.0 & \\
\hline $5-10 \mathrm{~cm} ; 06,05$ & 3.1 & 3.1 & & 0.049 & 0.049 & \\
\hline $10-15 \mathrm{~cm} ; 06,05$ & 2.6 & 2.6 & & 0.017 & 0.017 & \\
\hline $15-20 \mathrm{~cm} ; 06,05$ & 2.5 & & & 0.015 & & \\
\hline Blind Replicate Sample & 3.2 & & & not used & \multirow{3}{*}{\multicolumn{2}{|c|}{ More than $1000 \mathrm{X}$ the mean value }} \\
\hline Blind Replicate Sample & 4.9 & & & 0.0005 & & \\
\hline Blind Replicate Sample & 4.0 & & & 0.0005 & & \\
\hline Blind Replicate Sample & 4.2 & 3.7 & 0.94 & 0.0005 & 0.0042 & 0.007 \\
\hline 0-5 cm; 05.5, 05.5 & 2.8 & & & 1.5 & & \\
\hline Blind Replicate Sample & 3.4 & 3.1 & 0.39 & 0.95 & 1.2 & 0.36 \\
\hline $5-10 \mathrm{~cm} ; 05.5,05.5$ & 2.0 & & & 0.027 & & \\
\hline Blind Replicate Sample & 2.4 & & & 0.019 & & \\
\hline Blind Replicate Sample & 2.1 & 2.2 & 0.23 & 0.019 & 0.022 & 0.005 \\
\hline $10-15 \mathrm{~cm} ; 05.5,05.5$ & 1.4 & 1.4 & & 0.004 & 0.004 & \\
\hline $15-20 \mathrm{~cm} ; 05.5,05.5$ & 1.5 & & & 0.005 & & \\
\hline Blind Replicate Sample & 1.8 & & & 0.00050 & & \\
\hline Blind Replicate Sample & 1.8 & & & 0.00050 & & \\
\hline Blind Replicate Sample & 1.5 & 1.6 & 0.18 & 0.00050 & 0.0016 & 0.0021 \\
\hline $0-5$ cm; 04.5, 05.5 & 18.4 & & & 5.0 & & \\
\hline Blind Replicate Sample & 14.8 & & & 3.4 & & \\
\hline Blind Replicate Sample & 17.0 & 16.7 & 1.8 & 2.3 & 3.6 & 1.4 \\
\hline $5-10 \mathrm{~cm} ; 04.5,05.5$ & 8.3 & & & 1.3 & & \\
\hline Blind Replicate Sample & 6.1 & & & 0.7 & & \\
\hline Blind Replicate Sample & 6.0 & & & 0.6 & & \\
\hline Blind Replicate Sample & 7.7 & 7.0 & 1.2 & 2.0 & 1.1 & 0.65 \\
\hline $10-15 \mathrm{~cm} ; 04.5,05.5$ & 4.1 & & & 0.13 & & \\
\hline Blind Replicate Sample & 4.0 & & & 0.01 & & \\
\hline Blind Replicate Sample & 3.9 & & & 0.02 & & \\
\hline Blind Replicate Sample & 3.5 & 3.8 & 0.28 & 0.01 & 0.041 & 0.060 \\
\hline $15-20 \mathrm{~cm} ; 04.5,05.5$ & 3.3 & & & 0.053 & & \\
\hline Blind Replicate Sample & 3.3 & & & 0.040 & & \\
\hline Blind Replicate Sample & 3.1 & & & 0.037 & & \\
\hline Blind Replicate Sample & 3.1 & 3.2 & 0.11 & 0.040 & 0.042 & 0.0071 \\
\hline $0-5$ cm; 06, 04.5 & 160 & & & 34.1 & & \\
\hline Blind Replicate Sample & 116 & & & 24.9 & & \\
\hline Blind Replicate Sample & 84 & & & 18.6 & & \\
\hline Blind Replicate Sample & 120 & & & 30.7 & & \\
\hline Blind Replicate Sample & 93 & 114 & 30 & 13.8 & 24.4 & 8.4 \\
\hline $5-10 \mathrm{~cm} ; 06,04.5$ & 17.3 & & & 0.14 & & \\
\hline Blind Replicate Sample & 19.6 & & & 0.12 & & \\
\hline Blind Replicate Sample & 17.6 & & & 0.15 & & \\
\hline Blind Replicate Sample & 16.9 & 17.8 & 1.2 & 0.11 & 0.13 & 0.019 \\
\hline $10-15 \mathrm{~cm} ; 06,04.5$ & 13.5 & & & 0.023 & & \\
\hline Blind Replicate Sample & 13.6 & & & 0.00050 & & \\
\hline Blind Replicate Sample & 14.9 & & & 0.00048 & & \\
\hline Blind Replicate Sample & 14.1 & 14.0 & 0.65 & 0.00048 & 0.0062 & 0.011 \\
\hline $15-20 \mathrm{~cm} ; 06,04.5$ & 13.9 & & & 0.017 & & \\
\hline Blind Replicate Sample & 7.5 & & & 0.017 & & \\
\hline Blind Replicate Sample & 12.2 & & & 0.00050 & & \\
\hline Blind Replicate Sample & 11.6 & & & 0.00050 & & \\
\hline Blind Replicate Sample & 10.9 & 11.2 & 2.3 & 0.00050 & 0.0070 & 0.0089 \\
\hline (bottle labeled 033 \& 047) & 3.267 & & & 0.036 & & \\
\hline Median & & 6.5 & & & 0.19 & \\
\hline Mean & & 24 & & & 1.6 & \\
\hline Stdev & & 66 & & & 3.4 & \\
\hline Stderr & & 6.1 & & & 0.32 & \\
\hline No. & & 117 & & & 117 & \\
\hline & & Uranium & & & Beryllium & \\
\hline
\end{tabular}

